\title{
Relationship between family functionality and the quality of life of the elderly
}

\author{
Relação entre funcionalidade da família e qualidade de vida do idoso \\ Relación entre funcionalidad de la familia y calidad de vida del anciano
}

Edison Vitório de Souza Júnior'

ORCID: 0000-0003-0457-0513

Eduarda Raquel Viana'

ORCID: 0000-0003-3284-0883

Diego Pires Cruz"

ORCID: 0000-0001-9151-9294

Cristiane dos Santos Silva"

ORCID: 0000-0003-3822-1397

Randson Souza Rosa"I

ORCID: 0000-0001-7093-0578

Lais Reis Siqueira'V

ORCID: 0000-0002-6720-7642

Namie Okino Sawada

ORCID: 0000-0002-1874-3481

'Universidade de São Paulo. Ribeirão Preto, São Paulo, Brazil. "Universidade Estadual do Sudoeste da Bahia. Jequié, Bahia, Brazil.

I"' Universidade Federal de Minas Gerais. Belo Horizonte, Minas Gerais, Brazil.

"Universidade Federal de Alfenas. Alfenas, Minas Gerais, Brazil.

How to cite this article:

Souza Júnior EV, Viana ER, Cruz DP, Silva CS, Rosa RS, Siqueira LR, et al. Relationship between family functionality and the quality of life of the elderly. Rev Bras Enferm. 2022;75(2):e20210106. https:/doi.org/10.1590/0034-7167-2021-0106

Corresponding author: Edison Vitório de Souza Júnior E-mail: edison.vitorio@usp.br

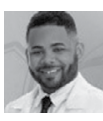

EDITOR IN CHIEF: Antonio José de Almeida Filho ASSOCIATE EDITOR: Alexandre Balsanelli

\section{ABSTRACT}

Objective: To analyze the correlation between family functionality and the quality of life of the elderly. Method: Sectional and correlational study conducted with 692 Brazilian elderly between July and October 2020. The elderly filled three instruments: biosociodemographic, family APGAR and WHOQOL-Old. The tests Kruskal-Wallis, Pearson correlation, and linear regression analyzed the data. The study considered a $95 \%$ confidence interval $(p<0.05)$ for all analyses. Results: The elderly with mild and severe family dysfunction presented worse quality of life when compared to the elderly with a functional family. All facets of quality of life correlated positively with family functionality. Conclusion: Family functionality is positively correlated with the quality of life of the elderly, therefore requiring the inclusion of the family in health care plans to identify potential family stressors early and plan interventions to solve the problems raised.

Descriptors: Public Health; Health of the Elderly; Family Relations; Quality of Life; Family.

\section{RESUMO}

Objetivo: Analisar a correlação entre a funcionalidade familiar e qualidade de vida de idosos. Método: Estudo seccional e correlacional conduzido com 692 idosos brasileiros entre julho e outubro de 2020. Os idosos preencheram três instrumentos: biossociodemográfico, APGAR de família e WHOQOL-Old. Os dados foram analisados com os testes de Kruskal-Wallis, correlação de Pearson e regressão linear. Considerou-se um intervalo de confiança de $95 \%(p<0,05)$ para todas as análises. Resultados: Os idosos com disfunção familiar leve e severa apresentaram pior qualidade de vida quando comparados com os idosos de família funcional. Todas as facetas da qualidade de vida se correlacionaram positivamente com a funcionalidade familiar. Conclusão: A funcionalidade familiar está correlacionada positivamente com a qualidade de vida dos idosos, necessitando, portanto, da inclusão da família nos planos de cuidados em saúde como forma de identificar precocemente potenciais estressores familiares e planejar intervenções para solução das problemáticas levantadas.

Descritores: Saúde Pública; Saúde do Idoso; Relações Familiares; Qualidade de Vida; Família.

\section{RESUMEN}

Objetivo: Analizar correlación entre la funcionalidad familiar y calidad de vida de ancianos. Método: Estudio seccional y correccional conducido con 692 ancianos brasileños entre julio y octubre de 2020. Ancianos rellenaron tres instrumentos: biosociodemográfico, APGAR de familia y WHOQOL-Old. Datos fueron analizados con los testes de Kruskal-Wallis, correlación de Pearson y regresión lineal. Considerado un intervalo de confianza de $95 \%(p<0,05)$ para todos los análisis. Resultados: Los ancianos con disfunción familiar leve y severa presentaron peor calidad de vida cuando comparados a ancianos de familia funcional. Todas las facetas de la calidad de vida se correlacionaron positivamente a la funcionalidad familiar. Conclusión: La funcionalidad familiar está correlacionada positivamente a la calidad de vida de los ancianos, luego necesitando, de la inclusión de la familia en los planes de cuidados en salud como manera de identificar precozmente potenciales estresores familiares y planear intervenciones para solución de las problemáticas planteadas.

Descriptores: Salud Pública; Salud del Anciano; Relaciones Familiares; Calidad de Vida; Familia. 


\section{INTRODUCTION}

As a result of reduced fertility rates and increased life expectancy, there is a significant increase in the number of elderly worldwide ${ }^{(1)}$. Studies estimate that, by the year 2050, the world population of individuals aged 60 and over will double ${ }^{(2)}$. In addition, in the same year, Brazil will occupy the sixth position among the countries with the highest number of elderly, which will correspond to $16 \%$ of its population ${ }^{(3)}$.

It is considered elderly, the individual aged 65 years or older in developed countries and 60 years or older in developing countries ${ }^{(4)}$, as is the case in Brazil. In addition, the aging process relates directly to several factors, which involve autonomy, physical, mental, and psychosocial health, financial independence family support, among others ${ }^{(5)}$.

Due to the social evolutions in recent years, there is a series of recurring transformations in the concept of the family, giving rise to new types of structure, organization, and relationships ${ }^{(6)}$. However, the family still establishes itself as a complex and dynamic system influenced by the cultural, historical context, and human relations in general, representing a source of care, attention, support, commitments, affection, and values ${ }^{(7)}$. It is a unique context that needs prospection since the actions of a member generate repercussions throughout the group ${ }^{(6)}$. In addition, as family members age, they experience changes in their composition, which, in turn, can influence family functionality and generate impacts on the balance of relations between their members ${ }^{(5)}$.

Thus, the family classification can be functional or dysfunctional. In a functional family, there is the presence of emotional and affective aspects. The members face conflicts and adversities unanimously with a view to resolution and emotional stability, using their resources to achieve efficiency in the environment. In this system, we can observe the fair distribution of roles and support among members ${ }^{(6)}$, the maintenance of relationships inside and outside the family context ${ }^{(8)}$, in addition to the harmony and integrity of the whole system ${ }^{(7)}$.

The dysfunctional family system is characterized by both incapacity ${ }^{(6)}$ and excessive care and/or protection without respect for the autonomy of family members ${ }^{(9)}$, making it unable to satisfactorily meet the needs of members. In this system, members are not able to face adversities and efficiently perform their functions, such as companionship, affectivity, adaptation, problem-solving, and development ${ }^{(6)}$. On the contrary, there is the prioritization of particular interests to the detriment of the group. This individualism, in turn, causes an imbalance in the family system and evolves into disharmony ${ }^{(7)}$, contributes to the emergence of pathological conditions and feeling of malaise among its members ${ }^{(10)}$, besides harming the autonomy and quality of life (QoL) of the elderly ${ }^{(6)}$.

Although QoL is a concept of the biomedical model and quite diverse, studies have addressed this topic a lot in recent years. As per the definition of the World Health Organization (WHO), which will be a reference in the present study, QoL is "an individual's perception of their position in life in the context of the culture and value systems in which he/she lives and about their goals, expectations, standards and concerns" ${ }^{\prime \prime 11)}$. It is a comprehensive concept, influenced in a complex way by personal beliefs, physical and psychological health, social relationships, and the environment ${ }^{(2)}$.

Therefore, the provision of care to the elderly should involve the individual, family, and community aspects that are part of their routine since there is no sense in considering aging vertically, in the figure of the individual, without conceiving the changes that occurred during the entire aging process ${ }^{(5)}$. Thus, new needs for longitudinal care arise to ensure the $\mathrm{QoL}$ of an aging population. Public authorities need to meet part of these needs, and families, another ${ }^{(1)}$.

Thus, finding strategies that improve QoL during the aging process is a challenge for scientific investigations in this field of knowledge ${ }^{(12)}$. To that end, this study hypothesizes that family functionality is directly correlated with the QoL of the elderly, i.e, those belonging to a functional system have better QoL. Based on our results, health professionals will have current scientific evidence on the impact of family relationships on the QoL of the elderly to implement targeted actions, precisely because of the need to help them age with good QoL ${ }^{(13)}$.

\section{OBJECTIVE}

To analyze the correlation between family functionality and the quality of life of the elderly.

\section{METHODS}

\section{Ethical aspects}

This study respected all ethical and bioethical recommendations for the development of research with human beings as recommended by Resolution No. 466/2012 of the National Health Council. Participants were informed about the risks and benefits of the study, signed the free and informed consent form (EULA) online, and received the second copy of EULA through the personal email, requested before responding to the instruments.

\section{Design, period and place of study}

It is a sectional and correlational study conducted according to the questions recommended by the strobe checklist. The data collection was carried out between July and October 2020, exclusively online, through Facebook.

\section{Sample; inclusion and exclusion criteria}

The number of participants required for the study was defined a priori using the sample calculation considering the following parameters: infinite population, $\alpha=5 \%$ and $\mathrm{Cl}=95 \%(\mathrm{za} / 2=1.96)$, which evidenced the need for at least 385 participants. However, because it was an online survey with elderly participants, it was chosen to add more than $50 \%$ of this value to the sample to compensate for possible incompleteness of answers and refusal rates. Thus, the final sample resulted in 692 participants who met the following inclusion criteria: being 60 years of age or older; being married, having a steady partner or being in a steady union; residing in the Brazilian territory and a community. The study excluded the elderly without internet access, active Facebook account, and those living in long-term institutions. 


\section{Study protocol}

The authors created an interactive website aimed at developing scientific research with the elderly. The website had the publication of a personalized invitation containing the name of the responsible persons, the institution of bond, inclusion criteria, telephone number, and the justification for the development of the study. This invitation included a hyperlink that gave direct access to the website that organized the instruments through the Google Forms platform. In addition, to expand the dissemination of the questionnaire to all over Brazil, the study chose to hire the post boosting service offered by Facebook, which distributed the publication monthly to the extent of the sample size required.

The study used three instruments: biosociodemographic, family APGAR and the World Health Organization Quality of Life - old (WHOQOL-Old).

The authors developed themselves the biosociodemographic instrument with questions related to religion, ethnicity, age group, gender, education, marital status, among others.

The study used the family APGAR instrument to evaluate the family functionality of the elderly. It is a validated and standardized instrument for the Brazilian population ${ }^{(14)}$ and structured in five questions that assess the adaptation, companionship, development, affectivity, and resolution capacity of the family. There are three possibilities of answers: 2 - always; 1 - sometimes; and 0 - never. Thus, the total points can vary between 0 and 10 . The instrument classifies the family functionality into a functional family ( 7 to 10 points), mild dysfunction ( 4 to 6 points), and severe dysfunction ( 0 to 3 points) ${ }^{(15)}$. In this study, the family APGAR showed good reliability through Cronbach's alpha of 0.877 . In addition, the study considered the composition formed by a couple as "family" (regardless of sexual orientation) with the presence or not of children since western culture considers the constitution by the legal union of people as one definition of marriage, including the fact that the family nucleus consisting of a couple and their children is observed as the main one ${ }^{(16)}$. This fact also justifies the reason the study delimited the sample to the elderly married, in a steady union, or with a stable partnership.

The study used the WHOQOL-Old instrument to evaluate the QoL of the elderly. It is a specific instrument validated for the Brazilian elderly population ${ }^{(17)}$. Its structure has 24 questions distributed in six facets of evaluation: sensory skills, autonomy, past, present, and future activities, social participation, death and dying, and intimacy ${ }^{(18)}$. The final score can vary between 24 and 100 points, depending on the recoding required before performing the analysis. In addition, the instrument does not recommend a cutoff point, and the highest/lowest score indicates, respectively, the best/worst QoL of the investigated. The Cronbach'S alpha of the WHOQOL-Old in this study was 0.887 , indicating good reliability. According to the facets, the instrument obtained the following values: sensory skills, $a=0.815$; autonomy, $a=0.682$; past, present and future activities, $\alpha=0.722$; social participation, $a=0.819$; death and dying, $a=0.839$; and intimacy, $a=0.881$.

\section{Analysis of results and statistics}

After the end of the collection, the statistical software IBM SPSS ${ }^{\odot}$ received the data for analysis. Initially, Kolmogorov-Smirnov tested the distribution of the data and evidenced the non-normality ( $p$ $<0.05$ ). Thus, the study used the nonparametric Kruskal-Wallis tests, with the application of Bonferroni's post hoc when necessary and the Pearson correlation ( $r$ ). It considered a $95 \%$ confidence interval $(p<0.05)$ for all statistical analyses. The software presented categorical variables using absolute and relative frequencies and quantitative variables through mean, median, and interquartile range $(\mathrm{IQ})$ positions. The linear regression model included the variables that presented $p$ value less than 0.05 in Pearson correlation analysis, with the Durbin-Watson test as a quality checker of the model. The beta $(\beta)$ coefficients and their respective confidence intervals showed the regression results.

\section{RESULTS}

Among the 692 participants elderly males predominated $(n=$ $408 ; 59 \%)$, between the ages of 60 and 64 years of age $(n=332$; $48 \%)$, catholic ( $n=376 ; 54.3$ per cent), self-declared Caucasian ( $n$ $=467 ; 67.5 \%)$, with complete higher education $(n=275 ; 39.7 \%)$, married $(n=440 ; 63.6 \%)$, living with the spouse for more than 20 years $(n=432 ; 62.4 \%)$, heterosexual men $(n=602 ; 87 \%)$, living in the south-eastern region of the country $(n=310 ; 44.8 \%)$, and they do not live with their children $(n=465 ; 67.2 \%)$. Regarding family functionality, the majority belonged to a functional system $(n=419 ; 60.5 \%)$, followed by mild dysfunction $(n=211 ; 30.5 \%)$ and, finally, severe dysfunction $(n=62 ; 9 \%)$.

Table 1 describes all biosociodemographic variables with some statistically significant association with family functionality and/ or QoL. Thus, it shows that the elderly female presented a better perception of $Q$ oL in sensory skills $(p<0.001)$. Concerning marital status, the elderly with a steady partner had better QoL in the facets "sensory skills" $(p=0.004)$ and "intimacy" $(p=0.004)$ when compared to the married elderly.

Regarding the time of living with the partner, there was a statistically significant difference between the elderly who lived between 6 and 10 years and those with more than 20 years for the facets "sensory skills" $(p=0.004)$ and "intimacy" $(<0.001)$. Finally, having children and not living with them was statistically associated with a functional family, compared to the elderly who do not have children $(p=0.005)$. The other association analyses are described in Table 1.

As observed in Table 2, in general, the elderly presented a better perception of QoL in sensory abilities, represented by the higher median, regardless of the family functionality's degree. Also, the elderly in the functional family have better QoL scores in all facets.

Table 3 shows that all facets of QoL are positively correlated with the family APGAR, indicating that these two variables present directly proportional behavior. The highest correlation found was between family functionality and the "intimacy" facet of QoL $(r=0.433 ; p<0.001)$.

The linear regression analysis demonstrated that family functionality remained positively associated with all facets of QoL of the elderly investigated, according to Table 4 . It means that these two variables present directly proportional behavior, i.e., when there is an increase in family functionality, there is also an increase in the QoL of the elderly. 
Table 1 - Association between biosociodemographic variables and family functionality and Quality of life of participants, Ribeirão Preto, São Paulo, Brazil, 2020

\begin{tabular}{|c|c|c|c|c|c|c|c|c|c|c|}
\hline & \multicolumn{3}{|c|}{ Familiar functionality } & \multicolumn{7}{|c|}{ Quality of life } \\
\hline & $\mathbf{F}$ & MD & DS & SS & AUT & PPFA & SP & DD & INT & QVG \\
\hline & \multicolumn{10}{|c|}{ Mean positions } \\
\hline \multicolumn{11}{|l|}{ Gender } \\
\hline Male & 347.31 & 346.16 & 346.03 & $319.54^{\ddagger}$ & 352.01 & 344.11 & 342.12 & 360.34 & 350.71 & 345.29 \\
\hline Female & 345.58 & 347.74 & 346.17 & $385.54^{\ddagger}$ & 340.25 & 351.49 & 354.08 & 326.65 & 341.76 & 348.97 \\
\hline$p$ value & 0.946 & 0.639 & 0.126 & $<0.001 *$ & 0.168 & 0.271 & 0.339 & 0.090 & 0.469 & 0.753 \\
\hline \multicolumn{11}{|l|}{ Marital status } \\
\hline Married & 354.82 & 346.37 & $338.30^{\ddagger}$ & $327.62^{\neq . \dagger}$ & 337.02 & 345.56 & 339.52 & 345.49 & $327.90^{\ddagger . \dagger}$ & 333.30 \\
\hline Steady union & 342.35 & 331.02 & $366.13^{\ddagger}$ & $381.11^{\ddagger}$ & 356.74 & 350.15 & 360.07 & 356.43 & $379.77^{\ddagger}$ & 371.57 \\
\hline Steady partner & 322.07 & 361.70 & 355.73 & $377.91^{\dagger}$ & 369.07 & 346.23 & 357.37 & 340.47 & $378.21^{\dagger}$ & 367.62 \\
\hline$p$ value & 0.148 & 0.311 & $0.011 *$ & $0.004^{*}$ & 0.223 & 0.974 & 0.470 & 0.804 & $0.004^{*}$ & 0.071 \\
\hline \multicolumn{11}{|l|}{ Living time } \\
\hline$\leq 5$ years & 329.56 & 358.34 & 351.60 & 368.49 & 368.57 & 359.30 & 363.77 & 349.77 & $387.61^{\ddagger}$ & 376.88 \\
\hline 6-10 years & 376.97 & 341.45 & 321.08 & $423.02^{\ddagger . \dagger}$ & 383.56 & 353.08 & 373.79 & 375.38 & $408.54^{\dagger}$ & 399.31 \\
\hline $11-15$ years & 305.56 & 365.21 & 368.73 & 366.81 & 358.79 & 348.42 & 369.44 & 326.47 & 383.44 & 354.41 \\
\hline $16-20$ years & 317.86 & 351.09 & 370.55 & $304.82^{\ddagger}$ & 347.90 & 333.64 & 317.64 & 347.58 & 335.90 & 336.49 \\
\hline$>20$ years & 353.25 & 341.92 & 344.33 & $332.08^{+}$ & 334.05 & 343.29 & 338.86 & 343.18 & $324.40^{\ddagger . \dagger}$ & 331.14 \\
\hline$p$ value & 0.117 & 0.804 & 0.057 & $0.004^{*}$ & 0.245 & 0.932 & 0.387 & 0.763 & $0.001 *$ & $0.046^{*}$ \\
\hline \multicolumn{11}{|l|}{ Live with children } \\
\hline Yes & 327.21 & 365.99 & 346.30 & 335.97 & 350.48 & 343.04 & 348.13 & 318.61 & 334.55 & 333.37 \\
\hline No & $359.48^{\ddagger}$ & 334.75 & 345.26 & 346.41 & 344.51 & 347.25 & 344.40 & 356.45 & 349.01 & 349.66 \\
\hline Does not have & $281.17^{\ddagger}$ & 394.78 & 363.56 & 403.50 & 351.08 & 355.10 & 364.92 & 366.00 & 377.43 & 375.32 \\
\hline$p$ value & $0.005 *$ & $0.013^{*}$ & 0.564 & 0.173 & 0.931 & 0.936 & 0.829 & 0.072 & 0.431 & 0.430 \\
\hline
\end{tabular}

*Statistical significance by the Kruskal-Wallis test ( $p<0.05) ; \neq,+$ Differences between groups by Bonferroni's post hoc; $F-$ functional; MD - mild dysfunction; SD - severe dysfunction; SS - sensory skills; AUT - autonomy; PPFA - past, present, and future activities; SP - social participation; DD - death and dying; INT - intimacy; GQV - general Quality of life.

Table 2 - Analysis of the Quality of life of the elderly according to family functionality, Ribeirão Preto, São Paulo, Brazil, 2020

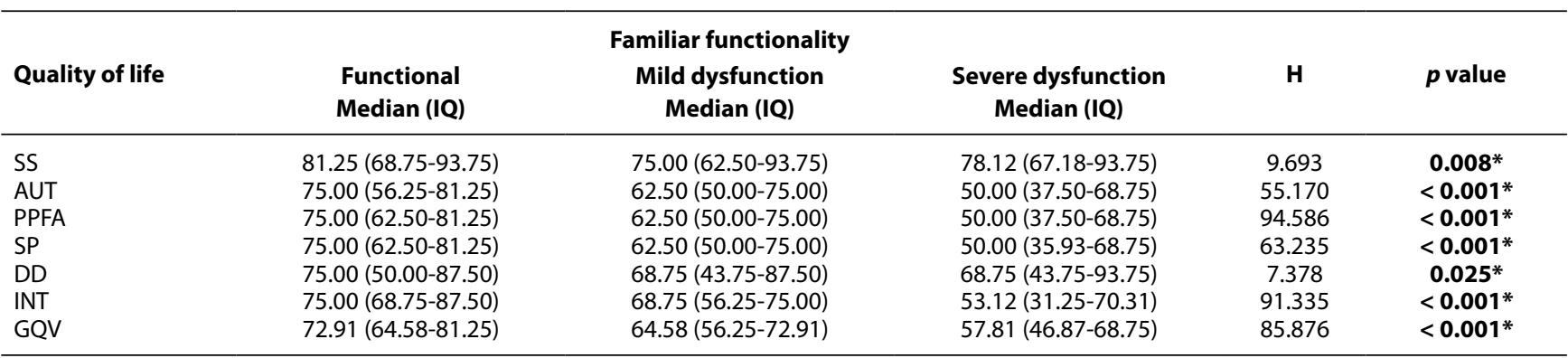

*Statistical significance by Kruskal-Wallis H test ( $p<0.05) ; I Q$ - interquartile range; SS - sensory skills; AUT- autonomy; PPFA - past, present and future activities; SP - social participation; MM - death and dying; INT - intimacy; GQV - general Quality of life.

Table 3 - Correlation between Quality of life and family functionality of the elderly, Ribeirão Preto, São Paulo, Brazil, 2020

\begin{tabular}{lcc}
\hline Facets of quality of life & \multicolumn{2}{c}{ Familiar functionality } \\
& $\mathbf{r}$ & $\boldsymbol{p}$ value \\
\hline Sensory skills & 0.109 & $\mathbf{0 . 0 0 4}$ \\
Autonomy & 0.330 & $<\mathbf{0 . 0 0 1}$ \\
Past, present and future activities & 0.409 & $<\mathbf{0 . 0 0 1}$ \\
Social participation & 0.335 & $<\mathbf{0 . 0 0 1}$ \\
Death and dying & 0.118 & $\mathbf{0 . 0 0 2}$ \\
Intimacy & 0.433 & $<\mathbf{0 . 0 0 1}$ \\
Overall quality of life & 0.416 & $<\mathbf{0 . 0 0 1}$ \\
\hline
\end{tabular}

\section{DISCUSSION}

The present study brings some biosociodemographic relevant information. It stands out, for example, the predominance of male participants (59\%), diverging from some national ${ }^{(19-22)}$ and international(23-25) studies developed with the elderly. This finding can be justified, in part, by a population-based longitudinal investigation ${ }^{(26)}$, developed with 1,197 elderly and identified the male gender as a variable associated with the maintenance of internet use over the four years investigated ${ }^{(26)}$. However, these gender differences in internet use may be related to individual characteristics, such as the time available for access, personality, motivations for using, and level of self-esteem ${ }^{(27)}$.

Table 4 - Final linear regression models for the independent variable (family functionality) and the facets of Quality of life, Ribeirão Preto, São Paulo, Brazil, 2020

\begin{tabular}{lccccccc}
\hline & SS & AUT & PPFA & SP & DD & INT & QVG \\
\hline $\boldsymbol{\beta}$ & 0.766 & 2.294 & 2.787 & 2.468 & 1.099 & 3.024 & 2.073 \\
IC95\% & $0.245-1.288$ & $1.803-2.785$ & $2.322-3.252$ & $1.948-2.987$ & $0.408-1.790$ & $2.554-3.494$ & $1.735-2.411$ \\
$p$ value & $\mathbf{0 . 0 0 4}$ & $<\mathbf{0 . 0 0 1}$ & $<\mathbf{0 . 0 0 1}$ & $<\mathbf{0 . 0 0 1}$ & $\mathbf{0 . 0 0 2}$ & $<\mathbf{0 . 0 0 1}$ & $<\mathbf{0 . 0 0 1}$ \\
Durbin-Watson & 2.075 & 1.871 & 1.871 & 1.905 & 2.001 & 1.983 & 2.028 \\
\hline
\end{tabular}

HS - sensory skills; AUT - autonomy; PPFA - past, present and future activities; SP - social participation; MM - death and dying; INT - intimacy; GQV - general Quality of life. 
In addition, the fact that most identify themselves as heterosexual $(87 \%)$ is also an important indicator that can help in the reorientation of public policies aimed at the elderly. Of the elderly in our sample, $13 \%$ belong to a minority group regarding sexual orientation and, considering the cultural context in which these elderly grew up and understood their desires, the study noticed that it is a relevant quantitative in the light of the field of gender and sexuality. It demonstrates the need for actions that welcome this public because, in addition to suffering the negative impacts of prejudice related to old age, it also suffers from prejudice linked to sexual orientation, generating the fear of assuming their sexuality as a consequence ${ }^{(28)}$.

Regarding family functionality, the majority of the elderly belonged to a functional system ( $n=419 ; 60.5 \%)$, followed by mild dysfunction ( $n=211 ; 30.5 \%$ ) and, finally, severe dysfunction $(n=62 ; 9 \%)$. These results corroborate other studies that identified this same hierarchy of family functionality in the elderly Brazilians ${ }^{(5)}$ and Chinese ${ }^{(23)}$.

The elderly female presented a better perception of QoL in sensory skills. This facet analyzes the impact of sensory losses (vision, touch, taste, hearing, and smell) on the ability of the elderly to interact in the social environment and the activities of daily living ${ }^{(18)}$.

Over the years, biological changes such as reduced sensory, cognitive, and walking ability arise. Such changes can limit the functionality of the elderly and increase their degree of dependence for carrying out daily activities. It is because sensory function and other factors explain $25 \%$ of the dependence of the elderly on basic activities and $21 \%$ of the instrumental activities of daily life $^{(29)}$. Thus, it is crucial to pay greater attention to the sensory abilities of the elderly, especially those of the male gender since they showed worse QoL in this facet and differed statistically from the female gender in the present study.

Concerning marital status, the elderly with a steady partner presented better QoL in the facets "sensory abilities" and "intimacy" when the study compared it to the married elderly. In this study, the elderly with a steady partner are those who maintain intimate relationships with a certain person but are not married or in a steady union. Although in the contemporary world marriage is represented by the conception of happiness, indissolubility ${ }^{(30)}$, and based on Christian principles, especially in western society ${ }^{(31)}$, such characteristics may not have belonged to the cultural context of the time when the elderly in this study got married.

One explanation lies in the fact that, in the past, marriage was carried out following the parents' choice to decide with whom their children would marry, solely to maintain political-economic interests, without in fact considering the feelings of the people involved in the marriage bond ${ }^{(31)}$. In addition, the strengthening of Conservative Conduct based on Christian morals that repudiated divorce marked that era. A qualitative study ${ }^{(30)}$ developed with 25 Catholic couples concluded that couples showed resistance to divorce and rigid adherence to the conception of a long-term marriage until the death of the spouse even in the face of the obstacles of life and marriage, demonstrating that Christian religion strongly repels the divorce still today.

Therefore, the study concludes that these characteristics may explain why the elderly with a steady partner presented better QoL in the facets "sensory skills" and "intimacy" when compared to the elderly married, as they had the freedom to choose their spouses and relate according to mutual desires and feelings.
Moreover, because they are not married, they are not subjected to Christian pressure to maintain the relationship until the end of life.

Moreover, the elderly who lived with their partners for a period between 6 and 10 years had better QoL in sensory skills and intimacy, when compared to those with more than 20 years of living together. The reason may lie in the aging process itself because as time passes and the organism ages, there is a decrease in physiological reserves and a greater possibility of losses. Thus, the best QoL may not be directly involved in the time of living with the partner itself, but in the life of the elderly, as the WHOQOL-Old instrument does not evaluate the QoL of the couple specifically, and yes, of the elderly in general.

The elderly who have children but do not live with them had a higher score statistically significant in family functionality compared to those who do not have children. This result corroborates the literature when it reveals that the absence of children is one of the risk factors for family dysfunctionality ${ }^{(5)}$.

Furthermore, the study emphasizes that living with family members is desired by the elderly because they believe that their family members will give support, care, and attention when they need $i^{(6)}$. However, it shows that the desire to reside with family members varies according to the relationship between its members, in addition to the factors that lead to this situation, such as dependence on financial resources and/or cohabitation as a way of being close. The study observed financial dependence in both cases: the elderly dependent on their children and the children dependent on the elderly parents. To that end, it deduced that the dependency of children on the elderly might negatively influence the old age and retirement of their parents, which ends up becoming another reason for care and/or concern. This characteristic refers to the phenomenon called "full nest," defined as the prolonged stay of young adult children in the home of the family of origin, still with financial and emotional dependence on their parents, a phenomenon that is increasingly frequent in our society ${ }^{(32)}$.

In general, the elderly in the present study presented a better perception of QoL in sensory skills, represented by the higher median, regardless of the degree of family functionality. This result confirms some studies ${ }^{(33-34)}$ and differs from another ${ }^{(35)}$, in which the elderly presented a better perception of QoL in the "death and dying"facet, and the "sensory skills" facet was the second with the highest score.

In addition, the elderly in the functional family had the best QoL scores in all facets, indicating that they present better QoL compared to those with some degree of family dysfunction. The family plays a significant role in society, such as providing support, affection, and protection, especially to the elderly population ${ }^{(6)}$. Therefore, good family functionality brings benefits that contribute to the maintenance and physical-psychological integrity of the elderly, provides a dynamic with greater effectiveness concerning the needs of the elderly and also contributes to the promotion of a good QoL in this age group ${ }^{(19)}$.

The studies that reveal that family functioning is a consistent ${ }^{(36)}$ and positive predictor of the QoL of the elderly, and satisfactory family functionality reduces the incidence of depression ${ }^{(23)}$, improves $\mathrm{QoL}^{(23,37)}$, and can positively influence active aging ${ }^{(19)}$ confirm the evidence. The dysfunctional family acts oppositely, i.e., exerting adverse impacts on the QoL of this population ${ }^{(38-39)}$. For that matter, we cite a study ${ }^{(24)}$ developed with 1,186 Chinese elderly, which showed that participants with family dysfunction 
experienced more negative emotions when compared to the elderly belonging to the functional family. In addition, the authors found that elderly members of the unhealthy family were more likely to develop depressive and anxious feelings ${ }^{(24)}$.

When it comes to the family system of the elderly, several relevant aspects affect the way they experience old age, namely the freedom and autonomy to endure this new stage of the life cycle healthily and enjoyably. For example, the family should promote freedom and autonomy in all areas of the elderly's life, including sexuality, which is considered a basic human need and which, due to its benefits in the health and QoL of this population ${ }^{(40)}$, has been encouraged, including among the elderly in palliative care $^{(41)}$ and those living with some type of dementia ${ }^{(42)}$.

Another point to consider is the role of the elderly in raising their grandchildren. The birth of a grandchild can impact both positively, bringing feelings of happiness and gratitude, and negatively, with the overload of care that grandparents may have. This is because the role of grandparents resembles that of parents, which can generate changes in such roles and even physical and emotional wear and tear as a result of dual motherhood with reduced physical capabilities ${ }^{(43)}$.

In this perspective, a study ${ }^{(43)}$ developed with 20 elderly women aged 60 years or more revealed that the grandmothers in close coexistence with their grandchildren demonstrated bigger challenges in the aging process whereas the elderly women who met their grandchildren sporadically attributed greater tranquility to old age. The authors suppose that the possible responsibilities of care on the part of grandmothers with their grandchildren compromise their satisfaction with aging ${ }^{(43)}$. Similarly, it happens when the elderly become the caregiver of their spouse, also becoming another factor capable of generating overload, illness, and guilt of the caregiver for the dependence of the partner ${ }^{(44)}$.

Therefore, there is a need for nursing professionals and all people involved in the care of the elderly to develop skills to critically and reflexively analyze issues related to the family functionality of this population. From this, it will be possible to build therapeutic projects that achieve effectiveness in family relationships and promote improvements in care for the elderly ${ }^{(20)}$.

\section{Limitations of the study}

The main limitation of the study concerns the non-probabilistic selection of participants, which compromises the external validity of the results. In addition, since data collection took place online in a social network, the participation in the study was limited to the elderly with internet access, reading and comprehension skills, which can be seen by the high level of education described in the biosociodemographic characterization. Thus, these results may not resemble the elderly with low education and a higher degree of socioeconomic vulnerability, which requires greater attention to the specific group of the study and caution in comparing our results. Finally, due to the new family settings and configurations that have emerged in recent years, the family APGAR instrument may not have been validated contemplating these new arrangements, and this may have limited the results found here.

\section{Contributions to the field of nursing}

This study contributes by revealing that family functionality correlates with the quality of life of the elderly. To that end, health professionals - especially primary care nurses - should include the family in the care plans as a way to early identify potential family stressors and plan interventions to solve the problems raised. Thus, it will be possible to contribute to the improvement of the QoL of the elderly through understanding and actions directed to their respective families.

\section{CONCLUSION}

This study showed that the elderly with mild and severe family dysfunction presented worse QoL when compared to the elderly from a functional family. In addition, all facets of QoL correlated positively with family functionality, which confirms the hypothesis and responds to the objective of the present study. However, it is worth noting that our results do not reflect the Brazilian elderly population, given the high socioeconomic standard of the participants and the non-probabilistic sampling of the study. Yet, it is worth investing in the inclusion of the family in health care plans to identify potential family stressors first and plan interventions to solve the problems raised. Thus, it will be possible to contribute to the improvement of the QoL of the elderly through understanding and actions directed to their families.

\section{FUNDING}

This work was carried out with the support of the Coordenação de Aperfeiçoamento de Pessoal de Nível Superior - Brazil (CAPES) - Financing Code 001.

\section{REFERENCES}

1. Ponce de León L, Mangin JPL, Ballesteros S. Psychosocial determinants of quality of life and active aging: a structural equation model. Int J Environ Res Public Health. 2020;17(17):6023. https://doi.org/10.3390/ijerph17176023

2. Risal A, Manandhar S, Manandhar K, Manandhar N, Kunwar D, Holen A. Quality of life and its predictors among aging people in urban and rural Nepal. Qual Life Res. 2020;29(12):3201-12. https://doi.org/10.1007/s11136-020-02593-4

3. Garbaccio JL, Tonaco LAB, Estêvão WG, Barcelos BJ. Aging and quality of life of elderly people in rural areas. Rev Bras Enferm. 2018;71(suppl 2):724-32. https://doi.org/10.1590/0034-7167-2017-0149

4. Santos Á da S, Santos VÁ, Albino A, Silveira RE, Nardelli GG. Sobre a psicanálise e o envelhecimento: focalizando a produção científica. Psic Teor Pesqui. 2019;35:e35423. https://doi.org/10.1590/0102.3772e35423 
5. Campos ACV, Rezende GP, Ferreira EF, Vargas AMD, Gonçalves LHT. Family functioning of Brazilian elderly people living in community. Acta Paul Enferm. 2017;30(4):358-67. https://doi.org/10.1590/1982-0194201700053

6. Elias HC, Marzola TS, Molina NPFM, Assunção LM, Rodrigues LR, Tavares DMS. Relation between family functionality and the household arrangements of the elderly. Rev Bras Geriatr Gerontol. 2018;21(5):582-90. https://doi.org/10.1590/1981-22562018021.180081

7. Andrade DMB, Rocha RM, Ribeiro IJS. Depressive symptoms and family functionality in the elderly with diabetes mellitus. Issues Ment Health Nurs. 2019;41(1)54-8. https://doi.org/10.1080/01612840.2019.1636167

8. Zhang Y. Family functioning in the context of an adult family member with illness: a concept analysis. J Clin Nurs. 2018;27(15-16):3205-24. https://doi.org/10.1111/jocn.14500

9. Neves BB, Goldim JR. Telecare for the elderly: coercion, confidence and satisfaction associated with its use. Rev Bras Geriatr Gerontol. 2018;21(4):464-71. https://doi.org/10.1590/1981-22562018021.170200

10. Cardona-Arango D, Segura-Cardona Á, Segura-Cardona A, Muñoz-Rodríguez DI, Agudelo-Cifuentes MC. La felicidad como predictor de funcionalidad familiar del adulto mayor en tres ciudades de Colombia. Hacia Promoc Salud. 2018;24(1):97-111. https://doi.org/10.17151/ hpsal.2019.24.1.9

11. The Whoqol Group. The world health organization quality of life assessment (WHOQOL): development and general psychometric properties. Soc Sci Med. 1998;46(12):1569-85. https://doi.org/10.1016/s0277-9536(98)00009-4

12. Govindaraju T, Sahle BW, McCaffrey TA, McNeil JJ, Owen AJ. Dietary patterns and quality of life in older adults: a systematic review. Nutrients. 2018;10(8):971. https://doi.org/10.3390/nu10080971

13. Zin PE, Saw YM, Saw TN, Cho SM, Hlaing SS, Noe MTN, et al. Assessment of quality of life among elderly in urban and peri-urban areas, Yangon Region, Myanmar. PLoS One. 2020;15(10):e0241211. https://doi.org/10.1371/journal.pone.0241211

14. Duarte YAO, Cianciarullo TI. Família: rede de suporte ou fator estressor: a ótica de idosos e cuidadores familiares. In: Escola de Enfermagem da USP. Livro programa: encontro internacional de pesquisa em enfermagem. São Paulo: EEUSP; 2002. p. 218, resumo $0389-0220$.

15. Vera I, Lucchese R, Munari DB, Nakatani AYK. Índex APGAR de Família na avaliação de relações familiares do idoso: revisão integrativa. Rev Eletronica Enferm. 2014;16(1):199-210. https://doi.org/10.5216/ree.v16i1.22514

16. Moimaz SAS, Fadel CB, Yarid SD, Diniz DG. Family Health: the challenge of a collective attention. Cienc Saude Colet 2011;16(Suppl 1):965-72. https://doi.org/10.1590/S1413-81232011000700028

17. Fleck MP, Chachamovich E, Trentini C. Development and validation of the Portuguese version of the WHOQOL-OLD module. Rev Saude Publica. 2006;40(5):785-91. https://doi.org/10.1590/S0034-89102006000600007

18. Scherrer Jr G, Okuno MFP, Oliveira LM, Barbosa DA, Alonso AC, Fram DS, et al. Quality of life of institutionalized aged with and without symptoms of depression. Rev Bras Enferm. 2019;72(Suppl 2):127-33. https://doi.org/10.1590/0034-7167-2018-0316

19. Ferreira YCF, Santos LF, Brito TRP, Rezende FAC, Silva Neto LS, Osório NB, et al. Funcionalidade familiar e sua relação com fatores biopsicossociais. Rev Humanidades Inov [Internet]. 2019 [cited 2020 Nov 25];6(11):158-66. Available from: https://revista.unitins.br/index. php/humanidadeseinovacao/article/view/1582

20. Silva DM, Vilela ABA, Souza AS, Alves MR, Silva DM, Souza TO. Evaluation of family functionality of elderly. J Nurs UFPE Online. 2013;7(9):5550-6. https://doi.org/10.5205/reuol.3529-29105-1-SM.0709201324

21. Bolina AF, Araújo MC, Haas VJ, Tavares DMS. Associação entre arranjo domiciliar e qualidade de vida de idosos da comunidade. Rev LatinoAm Enfermagem. 2021;29:e3401. https://doi.org/10.1590/1518-8345.4051.3401

22. Marzola TS, Molina NPFM, Assunção LM, Tavares DMS, Rodrigues LR. A importância do funcionamento das famílias no cuidado ao idoso: fatores associados. Rev Familia Ciclos Vida Saude Contexto Soc. 2020;8(1):78-86. https://doi.org/10.18554/refacs.v8i1.4440

23. Lu C, Yuan L, Lin W, Zhou Y, Pan S. Depression and resilience mediates the effect of family function on quality of life of the elderly. Arch Gerontol Geriatr. 2017;71:34-42. https://doi.org/10.1016/j.archger.2017.02.011

24. Dang $Q$, Bai $R$, Zhang $B$, Lin Y. Family functioning and negative emotions in older adults: the mediating role of self-integrity and the moderating role of self-stereotyping. Aging Ment Health. 2020;1-8. https://doi.org/10.1080/13607863.2020.1799940

25. Mengting L, Man G, Stensland M, Dong X. Family relationships and cognitive function among community-Dwelling U.S. Chinese older adults. Res Aging. 2021;43(1):37-46. https://doi.org/10.1177/0164027520939250

26. Krug RR, Xavier AJ, d'Orsi E. Factors associated with maintenance of the use of internet, EpiFloripa Idoso longitudinal study. Rev Saude Publica. 2018;52:37. https://doi.org/10.11606/S1518-8787.2018052000216

27. Diniz JL, Moreira ACA, Teixeira IX, Azevedo SGV, Freitas CASL, Maranguape IC. Digital inclusion and Internet use among older adults in Brazil: a cross-sectional study. Rev Bras Enferm. 2020;73(Suppl 3):e20200241. https://doi.org/10.1590/0034-7167-2020-0241

28. Araújo LF, Carlos KPT. Sexualidade na velhice: um estudo sobre o envelhecimento LGBT. Psicol Conoc Soc. 2018;8(1):218-37. https://doi. org/10.26864/pcs.v8.n1.10

29. Duran-Badillo T, Salazar-González BC, Cruz-Quevedo JE, Sánchez-Alejo EJ, Gutierrez-Sanchez G, Hernández-Cortés PL. Sensory and cognitive functions, gait ability and functionality of older adults. Rev Latino-Am Enfermagem. 2020;28:e3282. https://doi. org/10.1590/1518-8345.3499.3282 
30. Silva LA, Scorsolini-Comin F, Santos MA. Long-term marriages: personal resources as maintenance strategies of conjugal bond. Psico-USF. 2017;22(2):323-35. https://doi.org/10.1590/1413-82712017220211

31. Campos SO, Scorsolini-Comin F, Santos MA. Transformações da conjugalidade em casamentos de longa duração. Psicol Clin [Internet]. 2017 [cited 2021 Apr 30];29(1):69-89. Available from: http://pepsic.bvsalud.org/scielo.php?script=sci_arttext\&pid=S0103-56652017000100006\&ln $\mathrm{g}=\mathrm{pt} \& \mathrm{t} \operatorname{lng}=\mathrm{pt}$

32. Vieira ACS, Rava PGS. Ninho cheio: perspectivas de pais e filhos. Psicol Teor Prat [Internet]. 2012 [cited 2021 Apr 30];14(1), 84-96. Available from: http://pepsic.bvsalud.org/scielo.php?script=sci_arttext\&pid=S1516-36872012000100007

33. Almeida BL, Souza MEBF, Rocha FC, Fernandes TF, Evangelista CB, Ribeiro KSMA. Quality of life of elderly people who practice physical activities. Rev Pesqui Cuidado Fundam. 2020;12:432-6. https://doi.org/10.9789/2175-5361.rpcfo.v12.8451

34. Manso MEG, Maresti LTP, Oliveira HSB. Analysis of quality of life and associated factors in a group of elderly persons with supplemental health plans in the city of São Paulo, Brazil. Rev Bras Geriatr Gerontol. 2019;22(4):e190013. https://doi. org/10.1590/1981-22562019022.190013

35. Tavares DMS, Matias TGC, Ferreira PCS, Pegorari MS, Nascimento JS, Paiva MM. Quality of life and self-esteem among the elderly in the community. Cienc Saude Colet. 2016;21(11):3557-64. https://doi.org/10.1590/1413-812320152111.03032016

36. Ali S, Malik JA. Consistency of prediction across generation: explaining quality of life by family functioning and health-promoting behaviors. Qual Life Res. 2015;24:2105-12. https://doi.org/10.1007/s11136-015-0942-6

37. Wang J-K, Zhao X-D. Family functioning, social support, and quality of life for Chinese empty nest older people with depression. Int J Geriatr Psychiatry. 2012;27(11):1204-6. https://doi.org/10.1002/gps.2832

38. Wang J, He M, Zhao X. Depressive symptoms, family functioning and quality of life in Chinese patients with type 2 diabetes. Can J Diabetes. 2015;39(6):507-12. https://doi.org/10.1016/j.jcjd.2015.06.001

39. Araújo AA, Barbosa RASR, Menezes MSS, Medeiros IIF, Araújo Júnior RF, Medeiros CACX. Quality of life, family support, and comorbidities in institutionalized elders with and without symptoms of depression. Psychiatr Q. 2016;87:281-91. https://doi.org/10.1007/s11126-015-9386-y

40. Gatti MC, Pinto MJC. Velhice ativa: a vivência afetivo-sexual da pessoa idosa. Vinculo. 2019;16(2):133-59. https://doi.org/10.32467/ issn.19982-1492v16n2p133-159

41. Malta S, Wallach I. Sexuality and ageing in palliative care environments? Breaking the (triple) taboo. Australas J Ageing. 2020;39(Suppl 1):713. https://doi.org/10.1111/ajag.12744

42. Souza Júnior EV, Silva CS, Lapa PS, Trindade LES, Silva Filho BF, Sawada NO. Influence of sexuality on the health of the elderly in process of dementia: integrative review. Aquichan. 2020;20(1):e2016. https://doi.org/10.5294/aqui.2020.20.1.6

43. Souza KS, Castro JLC, Araújo LF, Santos JVO. Social representations of aging: a study with elderly grandmothers who take care of their grandchildren and grandmothers who do not. Cienc Psicol. 2018;12(2):293-7. https://doi.org/10.22235/cp.v12i2.1693

44. Batista EC. Experiências vividas pelo cônjuge cuidador da esposa em tratamento psiquiátrico. Fractal Rev Psicol. 2020;32(1):31-9. https://doi. org/10.22409/1984-0292/v32i1/5646 